\title{
Null mutation in human ciliary neurotrophic factor gene confers higher body mass index in males
}

\author{
Sandra D O’Dell*,1,3 ${ }^{\star}$ Holly E Syddall ${ }^{2}$, Avan Aihie Sayer ${ }^{2}$, Cyrus Cooper $^{2}$, Caroline HD Fall ${ }^{2}$, \\ Elaine M Dennison ${ }^{2}$, David IW Phillips ${ }^{2}$, Tom R Gaunt ${ }^{1}$, Patricia J Briggs ${ }^{1}$ and \\ Ian NM Day ${ }^{1}$ \\ ${ }^{1}$ Division of Human Genetics, University of Southampton School of Medicine, Duthie Building (MP 808), \\ Southampton General Hospital, Tremona Road, Southampton SO16 6YD, UK; ${ }^{2}$ MRC Environmental Epidemiology \\ Unit, Southampton General Hospital, Tremona Road, Southampton SO16 6YD, UK
}

Ciliary neurotrophic factor (CNTF) administration reduces weight in leptin-resistant mice via the signalling pathway normally activated by leptin. $A G>A$ null mutation in the CNTF gene results in complete absence of protein. We hypothesised that absence of CNTF could lead to diminished initiation of anorectic pathways, with consequent increase in body mass. In 575 Caucasian men aged 59- 73 years, the $A / A$ genotype (frequency $1.9 \%)$ was associated with a $10 \mathrm{~kg}$ increase in weight $(P=0.03,2 \mathrm{df})$ and $3 \mathrm{~kg} / \mathrm{m}^{2}$ greater BMI $(P=0.02,2 \mathrm{df})$. There was no effect in women. The $C N T F G>A$ null mutation therefore confers a moderate effect on obesity in males of $A / A$ genotype, who represent $1 \%$ of the general population.

European Journal of Human Genetics (2002) 10, 749-752. doi:10.1038/sj.ejhg.5200873

Keywords: ciliary neurotrophic factor CNTF gene; body mass index; population association study

\section{Introduction}

Ciliary neurotrophic factor (CNTF) belongs to the cytokine group of peptides, which cause anorexia, weight loss, and metabolic breakdown leading to cachexia. CNTF promotes the differentiation and survival of a variety of neuronal cell types such as sensory, sympathetic, ciliary and motor neurons and protective effects have been demonstrated in several animal models of neurodegenerative diseases. It was originally evaluated in humans suffering from motor neuron disease, but caused unexpected and substantial weight loss. ${ }^{1}$ Gloaguen et $a l^{2}$ showed that systemic administration of CNTF to obese leptin deficient $(o b / o b)$ mice and $d b / d b$ mice with a

\footnotetext{
*Correspondence: SD O'Dell; Division of Human Genetics, University of Southampton School of Medicine, Duthie Building (MP 808) Southampton General Hospital, Tremona Road, Southampton S016 6YD;

Tel: +44 (0)23 80796425; Fax: +44 (0)23 8079 4264;

E-mail: S.D.O'Dell@soton.ac.uk

${ }^{3}$ Current address: Medical Genetics Unit, St George's Hospital Medical

School, Cranmer Terrace, London SW17 ORE:

E-mail: s.o'dell@sghms.ac.uk

Received 3 April 2002; revised 1 July 2002; accepted 10 July 2002
}

mutated leptin receptor induced a rapid reduction in food intake and decrease in body weight, predominantly through loss of adipose tissue. CNTF treatment also reduced weight in leptin-resistant mice with diet-induced obesity (DIO) that typifies the human condition. One theory was that CNTF was working via a leptin-like mechanism, as CNTF receptors are related to leptin receptors and are similarly distributed within hypothalamic nuclei. $^{2}$ Ligand binding to both leptin- and CNTF-receptors activates the JAK-STAT (Janus kinase signal transducer and activator of transcription) pathway. Lambert et $\mathrm{al}^{3}$ have recently shown that CNTF induces STAT3 phosphorylation in the arcuate nuclei of leptinresistant obese mice, whereas leptin has no effect. As the two ligands initiate a common signalling pathway, failure of DIO mice to respond to leptin whilst retaining ability to respond to CNTF suggests leptin resistance reflects a failure of signal transduction at the leptin receptor. Leptin reduces appetite via melanocortin and neuropeptide Y (NPY) hypothalamic pathways, but so far only diminished NPYergic signalling appears responsible for the weight-reducing effect of $\mathrm{CNTF}^{4}$ 
Our study has set out to investigate whether endogenous CNTF has a potential role in human weight regulation. We hypothesised that absence of CNTF could lead to diminished initiation of anorectic pathways, with consequent increase in body mass. Takahashi et $a l^{5}$ first described a CNTF gene variant 'null' mutation in humans, which, they showed, results in total absence of protein in homozygotes and approximately halved expression in heterozygotes. If endogenous CNTF has a role in the control of feeding and metabolism similar to leptin, absence of functional protein could be associated with overweight. A previous case control study by Münzberg et $a l^{6}$ of the CNTF $G>A$ null mutation in relation to obesity in 439 children and adolescents, reported a higher $A$ allele frequency in obese (0.163) than in lean (0.148) individuals but this was not statistically significant. We have now investigated the relationship between weight, height, body mass index (BMI), waist, hip and waist/hip ratio (WHR) and CNTF $G>A$ genotype in a much larger sample of older individuals.

\section{Materials and methods Subjects}

The Hertfordshire cohort represents a sample of 965 healthy Caucasians (575 males and 390 females), born and living in Hertfordshire UK, aged 59-73 years at clinic, who are a subgroup of previously characterised subjects in ongoing studies of common diseases of late onset.

\section{DNA templates for ARMS PCR}

Genotyping was performed on a diluted long PCR amplicons of $3.1 \mathrm{~kb}$, prepared from genomic DNA stocks. Primers for the long PCR were as follows: forward CNTFLONGF 5'-TCCCATTAGTAGAGAATGCCCAGTG-3' and reverse: CNTFLONGR 5'-GAAAGCAAGGAAGAGAGAAGGGACT-3'(MWG Biotech, Milton Keynes, UK). Amplification was in 96-well Omniplates (Hybaid, Teddington, UK), each $10 \mu \mathrm{l}$ reaction containing $25 \mathrm{ng}$ of DNA, using a method essentially as described by Cheng et al. ${ }^{7}$

\section{CNTF null mutation ARMS PCR and genotyping}

The long PCR product was diluted 1:125 in water and $3 \mu \mathrm{l}$ were dried into microplates (GRI, Braintree, UK), prior to addition of PCR mix. The ARMS primers, sited in intron 1, were as follows: $G$ allele specific forward primer CNTFFA1: 5'-AGATGTGGTGTTTTCCTGTATCCCCG-3' and $A$ allele specific forward primer CNTFFA2: 5'AGATGTGGTGTTTTCCTGTATCCCCA-3', where the italicised base is a destabilising mismatch with antisense target, and base in bold type is complementary to the antisense of the specific allele. The common reverse primer, sited in exon 2, was CNTFRC1 5'-GGTAAAATGCACCTGCTGGTCTTCTAAG-3', giving an ARMS product of $214 \mathrm{bp}$. In the control PCR, CNTFLONGR served as the reverse primer and the forward primer, sited in exon 2, was CNTFFC2: 5'-GCCTTTGCATACCAGATAGAGGAGT-3', yielding a larger product of $284 \mathrm{bp}$. PCR amplification (1 cycle at $94^{\circ} \mathrm{C}$ for $6 \mathrm{~min} ; 17$ cycles at $94^{\circ} \mathrm{C}$ for $1 \mathrm{~min}, 60^{\circ} \mathrm{C}$ for $1 \mathrm{~min}, 72^{\circ} \mathrm{C}$ for $1 \mathrm{~min}$; 1 cycle at $72^{\circ} \mathrm{C}$ for $10 \mathrm{~min}$ ) was in 96-well Omniplates, each $10 \mu$ reaction containing

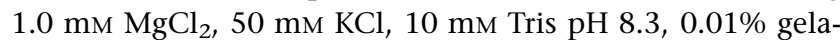
tin, $200 \mu \mathrm{M}$ each dNTP, 4.0 pmol each primer (MWG Biotech) and 0.2 U of Taq polymerase (Gibco, Paisley, UK). PCR product electrophoresis and genotype calling was as previously described by $\mathrm{O}^{\prime}$ Dell et al. ${ }^{8}$

\section{Statistical analysis}

Chi-squared test of Hardy-Weinberg equilibrium was applied to genotype data. Univariate associations between continuously distributed phenotype variables and genotype was assessed by one-way analysis of variance. All statistical analyses were carried out using STATA, release six. Results are presented as means and standard deviations.

\section{Results}

Anthropometric characteristics and CNTF $G>A$ genotype frequencies for men and women in the Hertfordshire cohort are given in Table 1 . The null allele $(A)$ frequency was 0.16 . The number of each of the $C N T F G>A$ genotypes in the total sample were as follows: $G / G 680$ (70.4\%); $G / A$ 267 (27.7\%); $A / A 18$ (1.9\%). Chi-squared test of HardyWeinberg equilibrium applied to the genotype frequencies in the total sample showed no significant deviation from those expected $\left(\chi^{2}=1.980 P=0.159,1 \mathrm{df}\right)$. There was no significant difference in $C N T F \quad G>A$ genotype frequency distribution by gender, (Pearson chi-squared=0.707; $P=0.702$ ). Table 2 shows tests of association between CNTF $G>A$ genotype and anthropometric variables in men. The $A / A$ genotype was associated with a $10 \mathrm{~kg}$ increase in mean weight compared with $G / G$ and $G / A(P=0.03,2 \mathrm{df})$ and a $3 \mathrm{~kg} / \mathrm{m}^{2}$ increase in BMI $(P=0.02,2 \mathrm{df})$. The $A / A$ genotype was also weakly associated with increased waist and hip circumferences, but the differences were not statistically significant. There were no significant associations between CNTF $G>A$ genotype and adult anthropometry in women.

Table 1 Characteristics of subjects

\begin{tabular}{lcc}
\hline Mean $(\mathrm{sd})$ & Men $(\mathrm{n}=575)$ & Women $(\mathrm{n}=390)$ \\
\hline Age (years) & $66.24(3.11)^{\mathrm{a}}$ & $66.37(2.79)$ \\
Weight $(\mathrm{kg})$ & $79.94(11.96)$ & $68.72(11.60)$ \\
Height $(\mathrm{m})$ & $1.72(0.064)$ & $1.60(0.059)$ \\
BMl $\left(\mathrm{kg} / \mathrm{m}^{2}\right)$ & $26.97(3.50)$ & $26.94(4.35)$ \\
Waist $(\mathrm{cm})$ & $98.62(9.97)^{\mathrm{b}}$ & $84.17(9.92)$ \\
Hip $(\mathrm{cm})$ & $105.19(7.43)^{\mathrm{a}}$ & $105.87(9.56)$ \\
Waist/hip ratio & $0.936(0.05)^{\mathrm{b}}$ & $0.795(0.050)$ \\
& & \\
CNTF genotype & & \\
frequency (\%) & & \\
GG & $407(70.8)$ & $108(27.7)$ \\
GA & $159(27.6)$ & $9(2.3)$ \\
$A A$ & $9(1.6)$ & \\
\hline${ }^{\mathrm{a}} n=572,{ }^{\mathrm{b}} n=574$. & &
\end{tabular}


Table 2 CNTF G/A genotype with respect to anthropometric variables

\begin{tabular}{|c|c|c|c|c|c|c|c|c|}
\hline & \multicolumn{4}{|c|}{ Men } & \multicolumn{4}{|c|}{ Women } \\
\hline & $\begin{array}{c}G G \\
(n=407)\end{array}$ & $\begin{array}{c}G A \\
(\mathrm{n}=159)\end{array}$ & $\begin{array}{c}A A \\
(\mathrm{n}=9)\end{array}$ & P value $e^{b}$ & $\begin{array}{c}G G \\
(n=273)\end{array}$ & $\begin{array}{c}G A \\
(\mathrm{n}=108)\end{array}$ & $\begin{array}{c}A A \\
(\mathrm{n}=9)\end{array}$ & $\mathrm{P}$ value \\
\hline Weight kg & $\begin{array}{c}79.64 \\
(11.89)\end{array}$ & $\begin{array}{c}80.12 \\
(11.72)\end{array}$ & $\begin{array}{c}90.22 \\
(15.88)\end{array}$ & 0.03 & $\begin{array}{c}69.24 \\
(12.12)\end{array}$ & $\begin{array}{c}67.52 \\
(10.56)\end{array}$ & $\begin{array}{l}67.28 \\
(5.11)\end{array}$ & 0.40 \\
\hline Height $\mathrm{m}$ & $\begin{array}{c}1.72 \\
(0.06)\end{array}$ & $\begin{array}{l}1.72 \\
(0.07)\end{array}$ & $\begin{array}{c}1.73 \\
(0.06)\end{array}$ & 0.82 & $\begin{array}{c}1.60 \\
(0.06)\end{array}$ & $\begin{array}{c}1.60 \\
(0.06)\end{array}$ & $\begin{array}{c}1.56 \\
(0.08)\end{array}$ & 0.16 \\
\hline BMI kg/m ${ }^{2}$ & $\begin{array}{l}26.85 \\
(3.45)\end{array}$ & $\begin{array}{l}27.11 \\
(3.49)\end{array}$ & $\begin{array}{l}30.10 \\
(4.79)\end{array}$ & 0.02 & $\begin{array}{l}27.14 \\
(4.56)\end{array}$ & $\begin{array}{l}26.39 \\
(3.86)\end{array}$ & $\begin{array}{l}27.69 \\
(2.67)\end{array}$ & 0.28 \\
\hline Hip cm & $\begin{array}{c}105.00 \\
(7.35)\end{array}$ & $\begin{array}{c}105.37 \\
(7.46)\end{array}$ & $\begin{array}{c}110.52 \\
(8.91)\end{array}$ & 0.08 & $\begin{array}{c}106.28 \\
(10.04)\end{array}$ & $\begin{array}{c}104.77 \\
(8.53)\end{array}$ & $\begin{array}{c}106.54 \\
(4.58)\end{array}$ & 0.37 \\
\hline $\begin{array}{l}\text { Waist/hip } \\
\text { ratio }\end{array}$ & $\begin{array}{c}0.936 \\
(0.054)\end{array}$ & $\begin{array}{c}0.935 \\
(0.049)\end{array}$ & $\begin{array}{c}0.953 \\
(0.046)\end{array}$ & 0.60 & $\begin{array}{c}0.793 \\
(0.052)\end{array}$ & $\begin{array}{c}0.797 \\
(0.048)\end{array}$ & $\begin{array}{c}0.802 \\
(0.033)\end{array}$ & 0.28 \\
\hline
\end{tabular}

Figures are mean (sd). ${ }^{\mathrm{a}}$ For men, GG $n=406$; GA $n=159 ; A A n=9 .{ }^{\mathrm{b}} \mathrm{ANOVA} 2 \mathrm{df}$.

\section{Discussion}

CNTF does not appear to play a physiological role in weight control comparable with leptin, since four $A / A$ individuals lacking CNTF among 151 healthy individuals studied by Takahashi et $\mathrm{al}^{5}$ and the eighteen $A / A$ individuals reported here were not obviously obese, whereas homozygous leptin gene mutants with no functional leptin are grossly so. ${ }^{9}$ Systemic CNTF can readily penetrate the blood-brain barrier $^{10}$ and so could act like leptin, as a peripherally produced satiety factor which activates receptors in the hypothalamus. However CNTF seems to operate independently of leptin at the receptor level, as CNTF induced STAT3 phosphorylation in DIO mice, but leptin had no effect. ${ }^{3}$ CNTF lacks a hydrophobic leader sequence ${ }^{11}$ and is not released from synthesising cells by the conventional secretory pathway. No attempts have been made to identify CNTF in adipose tissue, where, in common with other cytokines, it could exert an autocrine effect on lipogenesis.

Münzberg et $a l^{6}$ found no homozygous null individuals among 176 lean juvenile controls and only seven among 263 obese cases. They concluded that variants in the CNTF gene are unlikely to be associated with the development of early-onset obesity, but this does not preclude an influence on weight gain in later life. However as measurements of weight or BMI were not made in either study, the impact of CNTF absence on quantitative anthropometric variables in healthy individuals was unknown. We found no significant effect on BMI caused by a reduction in CNTF in heterozygotes of $50 \%$. Other factors may compensate for the deficiency of CNTF; the cytokines have pleiotropic actions based on common signal transduction pathways in target cells. In a leptin-sensitive individual the impact of CNTF would be expected to be minimal. However in leptin-resistant individuals (resistance acquired in later life) activation of the JAK/STAT pathway by CNTF could compensate for failure by leptin, provided that its release were linked to a rise in adiposity or some other indicator of energy sufficiency. In our study, male homozygous CNTF null mutants lacking CNTF are significantly heavier than normal homozygotes or heterozygous mutants. Any defect in CNTF signalling in leptin-resistant individuals could lead to a diminished ability to activate the JAK/STAT pathway and initiate anorectic effects. The absence of a significant effect in women may be due to the lower number of females studied than men or the effect may be reduced by female sex hormones, conditions that are known to affect gender-specific patterns of fat deposition. Further studies are required to confirm the significance of this finding, including replication of the association in a different sample and location of a site of endogenous CNTF expression relevant to adipostasis.

\section{Acknowledgements}

This work was funded by the UK Medical Research Council. Hope (formerly the Wessex Medical Trust) is thanked for support. Note: Patent application has been submitted based on the observations herein.

\section{References}

1 ALS CNTF Treatment Study Group: A double-blind placebocontrolled clinical trial of subcutaneous recombinant human ciliary neurotrophic factor (rHCNTF) in amyotrophic lateral sclerosis. Neurology 1996; 46: 1244-1249.

2 Gloaguen I, Costa P, Demartis A et al: Ciliary neurotrophic factor corrects obesity and diabetes associated with leptin deficiency and resistance. Proc Natl Acad Sci USA 1997; 94: 6456-6461.

3 Lambert PD, Anderson KD, Sleeman MW et al: Ciliary neurotrophic factor activates leptin-like pathways and reduces body fat, without cachexia or rebound weight gain, even in leptin-resistant obesity. Proc Natl Acad Sci USA 2001; 98: 4652 - 4657.

$4 \mathrm{Xu}$ B, Dube MG, Kalra PS et al: Anorectic effects of the cytokine, ciliary neurotropic factor, are mediated by hypothalamic neuropeptide Y: comparison with leptin. Endocrinol 1998; 139: 466-473.

5 Takahashi R, Yokoji $\mathrm{H}$, Misawa $\mathrm{H}$ et al: A null mutation in the human $C N T F$ gene is not causally related to neurological diseases. Nat Genet 1994; 7: 79-84. 
6 Münzberg H, Tafel J, Busing B et al: Screening for variability in the ciliary neurotrophic factor (CNTF) gene: no evidence for association with human obesity. Exp Clin Endocrinol Diabetes 1998; 106: $108-112$.

7 Cheng S, Fockler C, Barnes WM, Higuchi R: Effective amplification of long targets from cloned inserts and human genomic DNA. Proc Natl Acad Sci USA 1994; 91: 5695-5699.

8 O'Dell SD, Gaunt TR, Day INM: SNP genotyping by combination of 192-well MADGE, ARMS and computerised gel image analysis. BioTechniques 2000; 29: 500-502,504,506.
9 Montague CT, Farooqi IS, Whitehead JP et al: Congenital leptin deficiency is associated with severe early onset obesity in humans. Nature 1997; 387: 903-908.

10 Pan W, Kastin AJ, Maness LM, Brennan JM: Saturable entry of ciliary neurotrophic factor into brain. Neurosci Lett 1999; 263: $69-$ 71.

11 Lin LF, Mismer D, Lile JD et al: Purification, cloning, and expression of ciliary neurotrophic factor (CNTF). Science 1989; 246: $1023-1025$. 